\title{
An economic analysis of transhumance in the Central Spanish Pyrenees
}

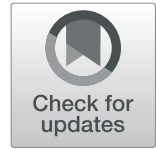

María E. Fernández-Giménez ${ }^{1 *}$ and John Ritten ${ }^{2}$

\begin{abstract}
The ecological and risk -management rationales for livestock mobility are well established. Yet, few studies evaluate the economic benefits and costs of maintaining or resuming mobile, extensive livestock production compared to sedentary or semi-extensive production. Here, we empirically evaluate pastoralists' claims that transhumance, a specific type of long-distance herd mobility, is a more profitable system compared to semi-extensive production in the Central Spanish Pyrenees. Specifically, we use enterprise budget data from transhumant and semi-extensive operations to develop a baseline typical sheep operation budget. We then use partial budget analysis coupled with economic simulations to determine the conditions under which transhumance by truck or on foot becomes profitable relative to semi-extensive production. We find that transhumance by foot is more profitable than transhumance by truck and that relative profitability compared to semi-extensive production depends on operational scale, feed prices, and the lambing rates (productivity) of each system. Over all simulated scenarios, transhumance is more profitable $64-78 \%$ of the time. This analysis thus provides initial evidence of the economic rationality of transhumance under contemporary environmental and economic conditions, filling a notable gap in research on the economics of transhumance. Future research could expand the analysis to cattle operations and to other regions of Spain, assess the full social and environmental benefits and costs of transhumance, and evaluate the effects of exogenous factors like drought on production costs and profitability to determine if transhumance is an adaptive strategy under a changing climate. The analysis we present could be used as a basis to develop and pilot test interactive budgeting tools that support herder decision-making and planning under economic and environmental uncertainty.
\end{abstract}

Keywords: Extensive livestock production, Semi-extensive production, Pastoral mobility, Partial budget analysis, Technical efficiency, Benefit-cost analysis, Aragón, Spain

\section{Introduction}

The decline of mobile pastoralism, especially nomadic pastoralism, is often reported (Fratkin and Abella Roth 2005; Humphrey and Sneath 1999), despite evidence of more dynamic ebbs and flows in mobile pastoralism historically (Honeychurch 2010; Fernandez-Gimenez and LeFebre 2006). The ecological and risk management rationales for livestock mobility are well established (Niamir-Fuller 1999; Scoones 1994). Yet, few studies evaluate the economic benefits and costs of maintaining or

\footnotetext{
* Correspondence: maria.fernandez-gimenez@colostate.edu

'Department of Forest and Rangeland Stewardship, Colorado State

University, Campus Mail 1472, Fort Collins, CO 80523-1472, USA

Full list of author information is available at the end of the article
}

resuming mobile, extensive livestock production compared to sedentary or semi-extensive production. Here, we empirically evaluate pastoralists' claims that transhumance, a specific type of long-distance herd mobility, is a more profitable system compared to semi-extensive production in the Central Spanish Pyrenees. Specifically, we use enterprise budget data from transhumant and semi-extensive operations to develop a baseline typical sheep operation budget. We then use partial budget analysis coupled with economic simulations to determine the conditions under which transhumance by truck or on foot becomes profitable relative to semi-extensive production. We find that across a range of parameter estimates for feed and pasture costs and lambing rates, 
both types of transhumance outperform semi-extensive systems under most scenarios. Transhumance on foot is the most profitable management system when costs for all systems are high or typical and lambing rates are low or typical. The economic advantage of transhumance increases with herd size, with little or no advantage over semi-extensive production at small herd sizes (500 ewes). The difference in profitability among systems is driven by lambing rates for all management systems and feed costs for semi-extensive systems.

Transhumance is a form of mobile livestock husbandry in which herders move domestic livestock flocks regularly and repeatedly between defined seasonal pasture areas. In Spain, transhumance has a long history (Rodriguez Pascual 2001; Ruiz and Ruiz 1986; Starrs 2018; Manzano Baena and Casas 2010), dating back as far as the Neolithic (Geddes 1983). The ecological and production rationales for Spanish transhumance are welldocumented (Manzano Baena and Casas 2010; Ruiz and Ruiz 1986; Starrs 2018; Perez and Saez 1990; Puigdefabregas and Fillat 1986), and recent works have revealed multiple ecosystem services associated with twenty-first century transhumance (Hevia et al. 2013; Hevia et al. 2016; Manzano and Malo 2006; Oteros-Rozas et al. 2012; Oteros-Rozas et al. 2014). However, Spain has also experienced an overall reduction in extensive livestock production in the second half of the twentieth century, including a decline in transhumance (O'Flanagan et al. 2011; Ruiz and Ruiz 1986; Chocarro et al. 1990; Manzano Baena and Casas 2010), as agricultural production restructured towards a more intensive industrial agriculture model. The principal drivers of this transition included rural outmigration to urban areas, resulting in agricultural labour deficits, and a parallel increase in the mechanization of agriculture (Chocarro et al. 1990; Estrada et al. 2010; Manzano Baena and Casas 2010). As agricultural communities in more remote and mountainous areas lost both human and livestock populations, the number of family-run farms declined, and intensive livestock production (feed-lot and stall-fed) increased with a concurrent increase in corporate farm ownership (Manzano Baena and Casas 2010) in order to meet demands of the growing urban market. These transitions were further reinforced with the introduction of the European Common Market in the late 1970s, which also contributed to price declines for pastoral products (Lefebvre et al. 2012; Estrada et al. 2010). In the twentieth century, transhumants also switched from walking with their herds to transporting them on trains, which was inexpensive. Over time, as road networks improved, more herders began to use trucks, train car conditions deteriorated, and train costs increased (Oteros-Rozas, personal communication). Eventually, the state-run train service eliminated livestock cars altogether in the 1990s, transhumant producers resorted to trucking or walking, and the cost and/or time needed for transhumance increased substantially (Bacaicoa Salaverri et al. 1993 cited in Oteros-Rozas et al. 2013). Thus, although conservation organizations increasingly highlight the value of transhumance for creating and maintaining valued habitat and cultural landscapes (Martin Casas 2003; GarzónHeydt 2004), and herders recognize a variety of benefits to transhumance (Oteros-Rozas et al. 2012; OterosRozas et al. 2014), the prevailing public narrative suggests that transhumance is a fading practice in rural Spain.

In contrast to the dominant discourse, we observed a revitalization of transhumance in one area of the Central Spanish Pyrenees, the Valles Occidentales (Western Valleys) of the Aragonese Pyrenees in the Province of Huesca. In this region, transhumance on foot and by truck never completely disappeared, but its prevalence diminished significantly in the 1980s and 1990s, due to the factors discussed above, as well as increasing competition for winter grazing in the lowlands, harsh living conditions for transhumants, and shepherds' preference to live at home with their families year-round (Fernández-Giménez 2019). Some claim that a general shift in the public perception of pastoralism, from an honourable profession to an occupation connoting poverty and backwardness, also likely contributed to the overall decline in extensive pastoralism, including transhumance (Pallaruelo 1993). In the central Pyrenees, transportation by train was never as popular as in some other regions of Spain (Pallaruelo 1993). During this period, most enterprises converted to a semi-extensive management model, where sheep and cattle graze communal high mountain pastures in the summer and spend the winter enclosed in barns and stall-fed on hay and grain. By 2010, only one operation continued to transhume on foot in one of the study villages. In 2018, however, several multi-generational herding families had resumed transhumance. Several new incorporations of young herders opted to use transhumance from their inception (Fernández-Giménez 2019). A variety of factors contributed to this resurgence (see Fernández-Giménez 2019 for a full discussion), including increased availability of low-cost winter pastures and technological advances that decrease labour requirements and improve quality of life for transhumant herders (e.g. electric fences, mobile phones). Herders reported in interviews that the primary reason for maintaining or taking up transhumance is its relative profitability compared to semi-extensive livestock husbandry, where animals are stall-fed in barns during the winter (Fernández-Giménez 2019). Herders who sought to expand their herd sizes were also more likely to take up transhumance. Herders' explanations align with literature on adoption of 
innovations that posits that relative advantage in terms of profitability is a key attribute of practices/innovations that influence adoptions (Rogers 1995).

Economic studies of extensive livestock production generally, and specifically mobile systems such as transhumance, are relatively scarce. Several papers have assessed the total economic value of extensive or mobile pastoralism in the context of national (Nyariki and Amwata 2019; Casas Nogales and Manzano Baena 2007), regional, and global (Davies and Hatfield 2007) economies, focusing on both market and non-market values. Research at the regional or sub-national level has used discrete choice experiments to assess the values attributed by respondents (pastoralists, local stakeholders) to different land uses (Mazzocchi and Sali 2019) or grazing management practices (Lutta et al. 2019). Other research has used data from producer surveys to compare economic performance of different extensive and intensive production systems using a variety of methods and metrics, such as technical efficiency (Galanopoulos et al. 2011; Gaspar et al. 2009; Perez et al. 2007; Shomo et al. 2010), benefit-cost ratios (Hamadeh et al. 2001; Qtaishat et al. 2012), and relative profitability based on partial budget analyses (Legesse et al. 2005). Findings from these studies offer mixed evidence on the economic benefits of extensive mobile production systems. Work from Jordan (Qtaishat et al. 2012) and Lebanon (Hamadeh et al. 2001) showed that benefit-cost ratios were highest in mobile extensive systems, even when profitability was lower. Two different studies in Spain found technical efficiency was generally high in extensive systems, even when productivity per ewe was low, due to low costs and management systems highly adapted to exploit available resources (Gaspar et al. 2009; Perez et al. 2007). Other studies found technical efficiency in transhumant systems was low (Galanopoulos et al. 2011), or lower than that in more intensive production systems (Shomo et al. 2010). A partial budget analysis of feeding trial results in Ethiopia for two goat species found that for one breed, semi-extensive was most profitable, followed by extensive, while intensive was least profitable. For the other breed, no system was profitable, but losses were minimized in the extensive system (Legesse et al. 2005). In summary, evidence exists for the total economic value (Davies and Hatfield 2007; Nyariki and Amwata 2019) and perceived social value (Lutta et al. 2019; Mazzocchi and Sali 2019) of extensive, mobile livestock production. However, determining the relative profitability of transhumance compared to more settled production systems at the firm level is critical to understanding producers' decisions to take up or maintain this practice.

In order to empirically evaluate Pyrenean herders' widespread perception of the profitability of transhumance, we collected primary data on the costs and revenues associated with three types of operations, used these to parameterize a typical "model operation", and compared the three operation types using a Monte Carlo simulation. This approach is based on a simple partial budget analysis approach (Alimi and Manyong 2000) that has been applied to ranch decision-making in the western USA. The partial budget analysis together with a sensitivity analysis is used to compare the relative cost and revenue from different management choices, such as the alternative choice to sell cattle or buy hay in a drought (Feuz and Ritten 2014), under a range of cost and revenue scenarios. In this analysis, we compared three alternative management choices: stable-feed ewes during the winter, transhumance on foot to winter pastures, and transhumance by truck to winter pastures under multiple cost and revenue scenarios.

\section{Study area}

This study takes place in the westernmost valleys of the Aragonese Pyrenees, in the Province of Huesca, an area known as the Valles Occidentales or Western Valleys (Fig. 1). Most of the herders interviewed reside in the villages of Ansó or Hecho, although one is from the hamlet of Novés, at the easternmost edge of the study region. The territories used by transhumants range from the summer pastures in the high Pyrenees (maximum $2700 \mathrm{~m})$ to the winter pastures in the Ebro River Valley $(\sim 500 \mathrm{~m})$ with corresponding variability in mean annual precipitation from $>1800 \mathrm{~mm}$ in the high mountains to $<400 \mathrm{~mm}$ in the valley (Cuadrat et al. 2007). The seasonality of precipitation also varies, with the majority of precipitation falling in the form of snow from November to February in the mountains while peak precipitation in the valley occurs as rainfall from April through June (Cuadrat et al. 2007). Similarly, mean annual temperatures range from $4-6{ }^{\circ} \mathrm{C}$ in the high mountains to $14{ }^{\circ} \mathrm{C}$ in the Ebro Valley. The mean minimum temperature in the mountains is $<0{ }^{\circ} \mathrm{C}$ and the mean minimum in the valley is $>9{ }^{\circ} \mathrm{C}$, with corresponding mean highs of 6 $8{ }^{\circ} \mathrm{C}$ in the mountains and $20-22^{\circ} \mathrm{C}$ in the valley (Cuadrat et al. 2007). The variability of precipitation and temperature over space and seasons is an important factor driving the availability and quality of forage over the year, and a principal driver for the development of transhumance as a management strategy (Puigdefabregas and Fillat 1986).

Ansó and Hecho are considered among the most conservative communities in this region of the Pyrenees with respect to maintaining traditional pastoral culture, which has made them the focus of previous studies on pastoralists' traditional ecological knowledge (Fernandez-Gimenez and Estaque 2012; Fernandez-Gimenez and Fillat Estaque 2012). Both villages maintain their 


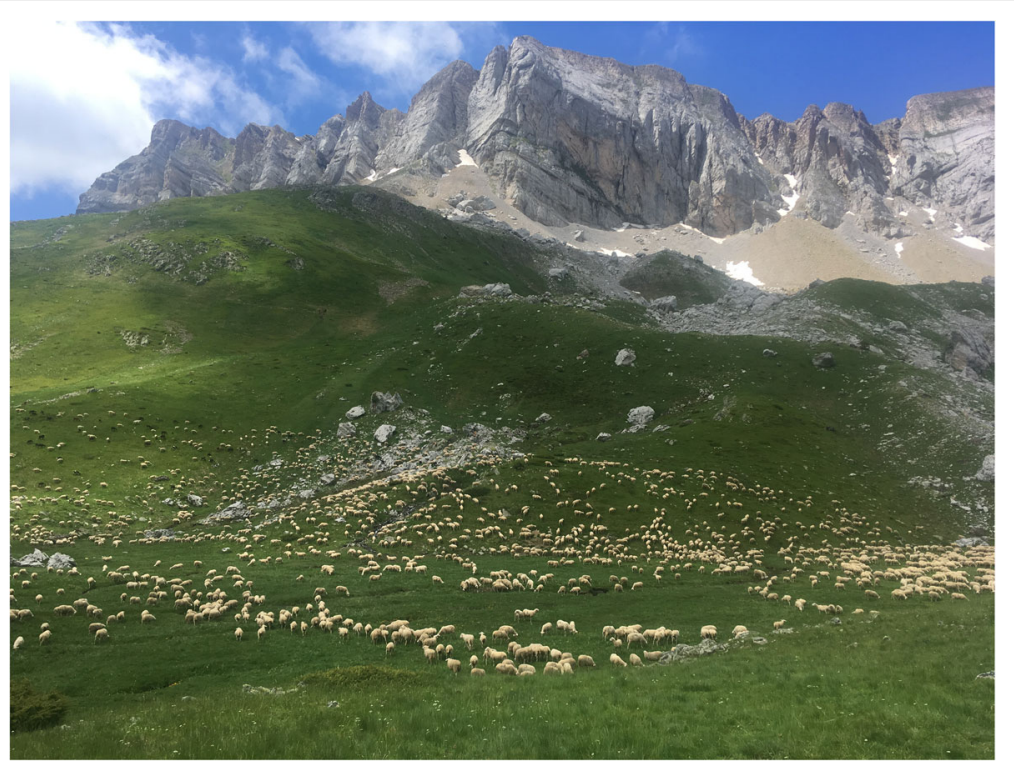

Fig. 1 Sheep grazing in summer pastures in the high Pyrenees

distinct local dialects of Aragonese, residents of Ansó speaking Ansotano and those of Hecho, speaking Cheso. In 2018, Ansó's human population numbered 411 and Hecho's 568 (the valley of Hecho had 852), and the hamlet of Novés had 32 inhabitants (Foro-Ciudad.com 2019). Ansó reported 20 livestock operations with a total of 5829 sheep, 145 goats, 924 cattle, and 19 horses. Hecho reported 43 operations with 6380 sheep, 472 goats, 2010 cattle, and 15 horses (Instituto Aragonés de Estadística 2018a; b).

Most of the transhumant operators we interviewed for this study identify Ansó or Hecho as their home town (pueblo), rather than the town where they spend the winter months. One identifies equally with both summer and winter villages, or with neither, stating, "I am from the mountains; from where my sheep are." Both Ansó and Hecho are typical villages of the central Aragonese Pyrenees, with a dense cluster of tall stone buildings, cobblestone streets, and a cathedral seemingly out of proportion to the size of the village in population and area. Privately owned hayfields and meadows surround Hecho on the valley bottom, while the steep slopes around Ansó prevent cultivation, and most of the formerly open hillside pastures have been lost to encroaching shrubs. The area of the Valles Occidentales became a regionally-administered natural park in 2007 and beckons tourists with its natural beauty and cultural heritage. Picturesque Ansó was recently designated one of the "prettiest pueblos of Spain".

The abundant and high-quality summer pastures in the high Pyrenees are the communal property of each village (Fig. 1). Ansó's community grazing rights date to the reign of King Jaime I in 1272. Any individual who is officially resident in the village for more than 2 years has the right to graze summer pastures for a minimal fee of 2 euros per sheep for the entire summer. Specific summer grazing areas known as puertos are allocated to stockgrowers by each village's livestock association. If the amount of forage available exceeds the demand by village stockgrowers, the excess is sold to herders from other villages or regions at a higher price. The availability and affordability of these rich natural pastures historically drove the region's mountain livestock industry and remain a major driver today. The two valleys' differing terrain influences their use of land and favoured species of livestock. The steepness of Ansó valley makes cultivation of hay and crops impossible. Thus, Ansó historically favoured sheep production and was renowned for its fine-wool local sheep breed, the Ansotana. The broader Hecho valley allows for hayfields, making it more favourable for cattle, although both villages raise both types of livestock, as well as smaller numbers of goats and horses. Here, we focus on sheep transhumance, because today, only sheep operators practise long-distance $(>100 \mathrm{~km}$ ) transhumance on foot.

Figure 2 illustrates the two most common transhumant routes used by the interviewed herders. Residents of Ansó and Hecho practise "descending" transhumance, as their home villages are located in the Pyrenees and they descend to the Ebro River valley in the winter. The western route descends from the valley of Ansó and crosses the pre-Pyrenees mountains to an agricultural area known as Cinco Villas. The eastern route follows the Río Aragón Subordán down the valley of Hecho, 


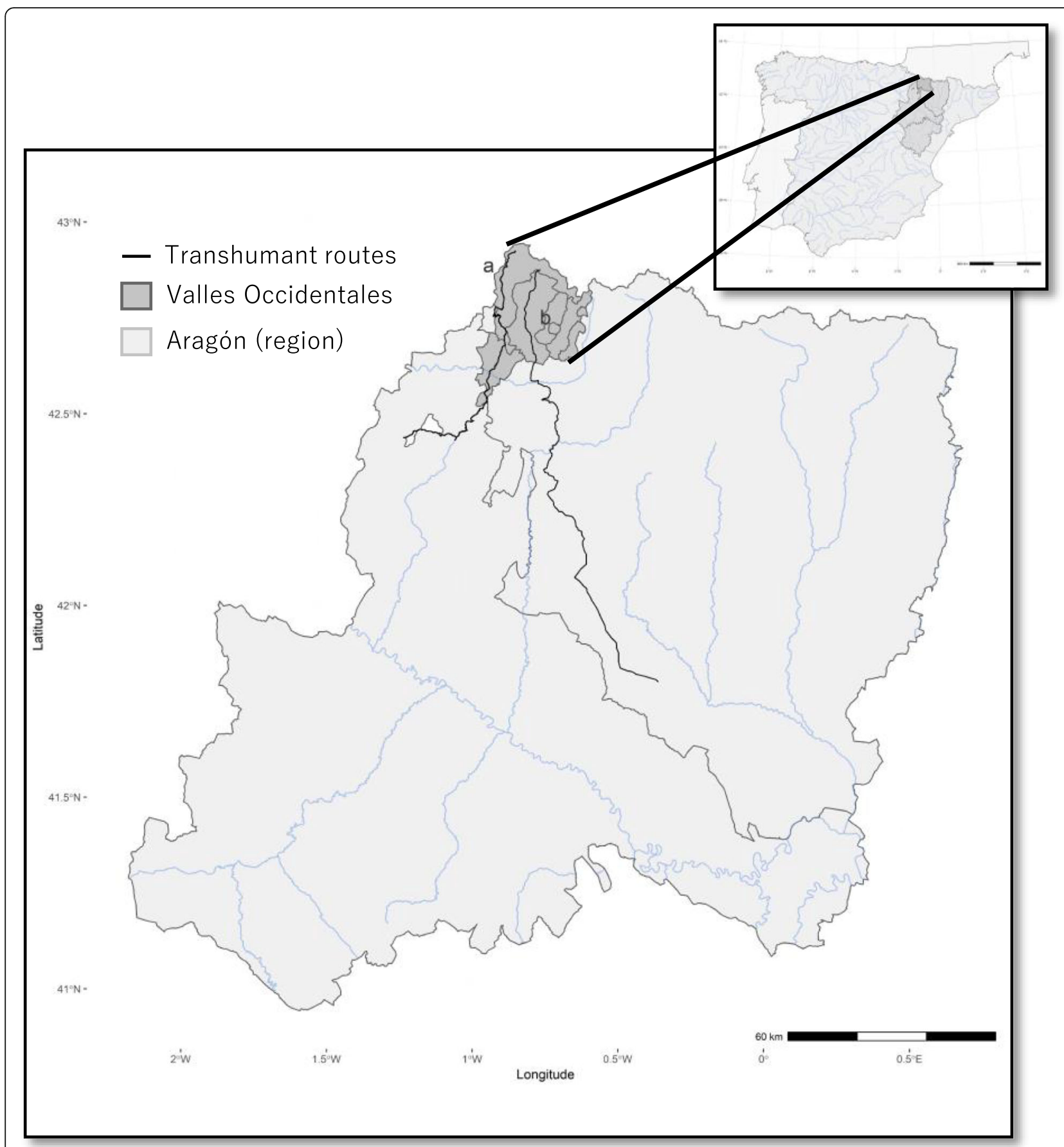

Fig. 2 Map of the study areas showing the two most common transhumant routes

passes the impressive rock formations of the Mayos de Riglos, and concludes in the region of Monegros (Fig. 3). The shepherds mostly follow established drove roads (cañadas and veredas), which sometimes overlap with paved roads and sometimes are little more than rough trails through the mountains (Fig. 4). Although the government is legally obliged to maintain these stock drove roads (vías pecuarias), transhumants frequently complain about the poor conditions of the drove roads. Each transhumance by foot operation takes a slightly different approach. The largest operator relies on the unpaid assistance of friends and relatives, in addition to a hired herder. The shepherd and helpers spend the night camping alongside the flock, which they enclose within a 


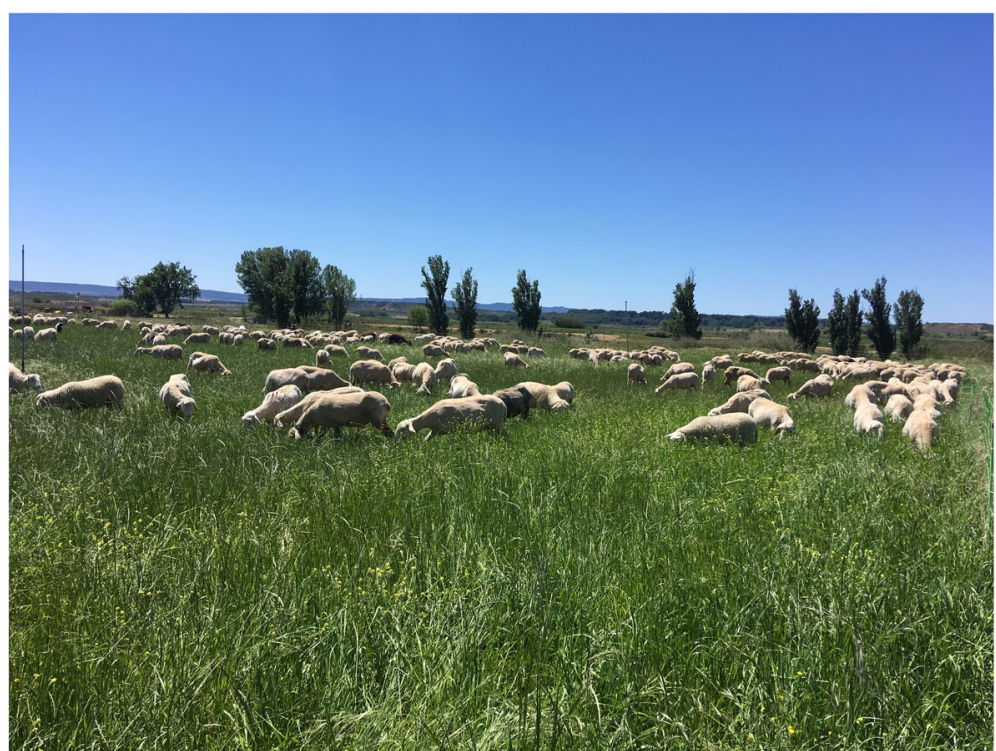

Fig. 3 Sheep grazing in winter pastures in Monegros

portable electric fence each evening. Other transhumants by foot leave their penned flocks under the watch of guard dogs overnight and return to their villages to sleep. All of the transhumants by foot have one person who drives a truck and trailer behind the herd, to carry food and camping equipment and to pick up weak or lame animals along the way. Three of the five transhumants interviewed spend the winter in a different village, near their winter grazing areas in Cinco Villas or Monegros, living in a rented apartment or a family-owned house. One had an arrangement where their rented winter grazing included a shepherd and one commuted daily from Hecho to their winter grazing place.

\section{Methods}

In order to evaluate empirically herders' widespread perception of the relative profitability of transhumance, we collected primary data on the costs and revenue associated with three types of operations, used these to parameterize a typical "model operation", and compared the operation types under several different scenarios. This approach is based on a simple partial budget analysis (Alimi and Manyong 2000; Kay et al. 2016), an approach that has been applied to ranch decision-making in the western USA (Feuz and Ritten 2014), alternative weaning and feeding strategies in the USA (Eisele et al. 2012), and small-holder agricultural decision-making

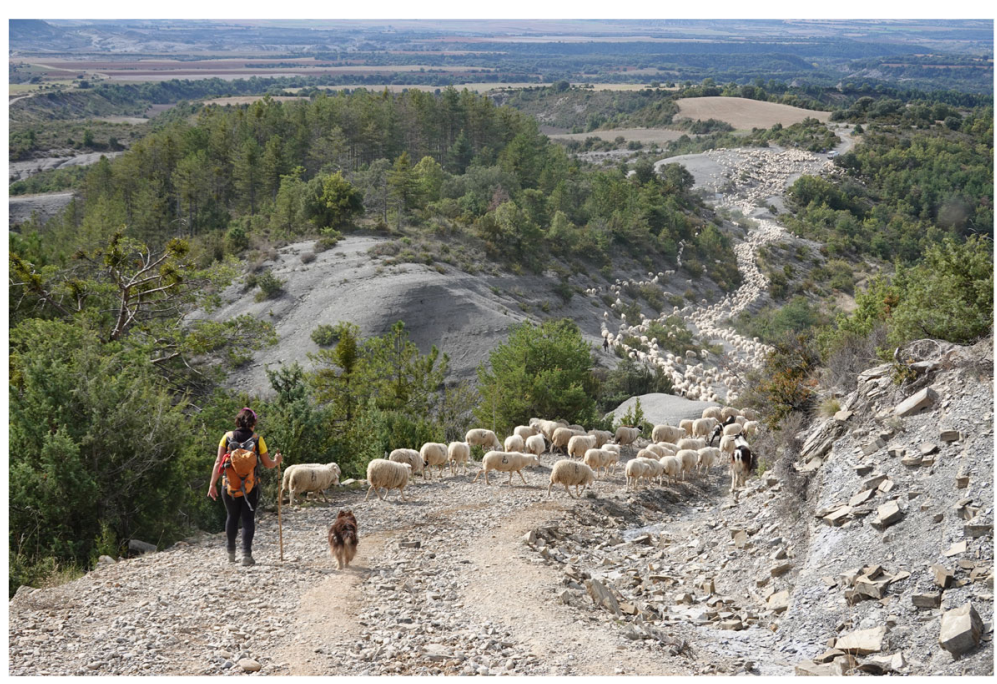

Fig. 4 Transhumant herd descending from the Pyrenees to winter grazing in Cinco Villas 
worldwide (Alimi and Manyong 2000; Bamire and Manyong 2003; Lutta et al. 2019; Feuz and Ritten 2014). The partial budget analysis together with a sensitivity analysis is used to compare the relative cost and revenue from different management choices, such as alternative weaning and feeding strategies. Partial budgeting does not determine absolute profitability but is "a formal and consistent method for calculating the expected change in profit from a proposed change in the farm business" (Kay et al. 2016, page 216). As partial budgeting is a tool to determine if a proposed alternative is more or less profitable than an existing alternative, only information about differences in costs and revenues is required. Partial budgets rely on four categories: (1) additional costs of the change, (2) reduced revenue associated with the change, (3) additional revenue associated with the change, and (4) reduced costs associated with the change. Comparing the total of the additional revenue and reduced costs with the additional cost and reduced revenues will show if one alternative is more or less profitable than another alternative. In this analysis, we compare three alternative management choices: stablefeed ewes during the winter, transhumance on foot to winter pastures, and transhumance by truck to winter pastures over a suite of production and price variables.

\section{Data collection}

We used a worksheet to collect detailed information on costs and revenues for six sheep operations in the Valles Occidentales that practise three different management systems: transhumance on foot $(n=3)$, transhumance by truck $(n=2)$, and semi-extensive production $(n=2)$ where sheep graze on communal summer pastures and are stable-fed during winter. One operation was in the process of converting to transhumance by truck, and data from this operation were used to parameterize both the semi-extensive and transhumance by truck systems. The transhumant operations interviewed for this article included three based in Ansó, accounting for $\sim 60 \%$ of all the sheep in the census; three based in Hecho, accounting for $30 \%$ of Hecho's sheep census; and one in Novés. Operations ranged in size from 500 ewes to 2700 ewes, with four operations of roughly 1000-2000 ewes. Three of the producers specialized in a local sheep breed, the Ansotana, while the others had raised more widespread commercial types, such as the Aragonesa and Navarra breeds. Two of the larger operations (one semi-extensive and one transhumant) paid hired shepherds while the others relied entirely on family labour and informal unpaid assistance most of the year.

Because each operation differs in multiple ways, and we obtained data from only two or three operations of each type, we did not attempt a direct statistical comparison. Rather, we used the data from the six different operations to create a believable "typical" sheep operation for the region as a baseline. We constructed an initial budget and conducted a preliminary analysis based on five interviews. All costs and revenues are reported in 2018 values. We showed these results to three additional producers who highlighted missing costs and flawed assumptions and provided three additional detailed budgets. To determine a typical level of subsidy for an operation, we consulted the publicly available information on European Union Common Agricultural Policy (EU CAP) payments for each of the study communities to determine exactly how much each operation received in 2018. The values for the interviewed operations varied greatly, from 10,000 to 90,000 euros, but for all the operations that receive subsidies in each village, 30,000 euros is a typical amount for a mid-sized (1000 ewes) operation. All of the operations included in our analysis received similar categories of EU CAP payments, including a basic payment, payments for environmentally beneficial practices, agro-environmental and climate payments, and payments for use of less favourable (i.e. mountain) areas. To avoid perverse incentives for overproduction, EU CAP makes payments based on the number of hectares grazed rather than the number of animals produced. Data from all seven budgets were used to develop the final base models of each operation type. These data, and additional research on typical production costs for semi-extensive and extensive sheep production (e.g. Feuz et al. 2013), were used to provide productivity and price parameter estimates used in the simulation.

\section{Baseline models and assumptions}

The basic assumptions in the baseline budget for each operation type are depicted in Tables 1 and 2, and the assumptions on production characteristics (lambing percentages, replacement rate, etc.) in Table 3. Assumptions on unit prices were developed by combining data from the seven actual operation budgets to determine a cost that would be most representative of herders residing in Ansó or Hecho with derechos de vecinos (residents' rights) to communal summer, spring, and fall pastures associated with these villages. These combinations were not necessarily averages, because one of the actual operations was not located in Ansó or Hecho and thus had substantially higher summer pasture rental costs than are typical for the westernmost valleys.

\section{Scenario comparison and sensitivity analysis}

First, we conducted baseline analyses for each operation type using the assumptions in Tables 1,2 and 3, varying only the number of ewes $(500,1000,2000)$. Based on our interviews, for operations of 2000 sheep or more, we assumed two workers for social security and 12 months of a hired herder's salary (Table 2). Next, following the 
Table 1 Costs that vary between semi-extensive and transhumant operations. At the time of data collection in fall 2018, 1 euro = 1.14 US dollars

\begin{tabular}{llll}
\hline Costs (euros) & & & \\
\hline & Units & Semi-extensive & Transhumant \\
\hline Winter pasture_daily cost per ewe* & ewe days & 0.06 \\
Grain, hay, and straw for sheep_daily cost per ewe* & ewe days* & 0.26 & 0.01 \\
Vehicle & km per day & 30 & 35 \\
Annual vehicle maintenance and repair & cost per year & 3000 & 5000 \\
Housing —annual rent (€250/month for 6 months) & cost per year & 0 & 1500 \\
\hline
\end{tabular}

*ewe days $=$ number of ewes $\times$ number of days. Calculations assume each ewe spends 155 days on winter pasture (transhumant) or winter stall feeding (semi-extensive)

partial budget analysis methodology, we conducted a simple sensitivity analysis comparing the relative profitability of the semi-extensive operation to transhumance by foot and transhumance by trucks under different revenue and cost scenarios. This analysis shows relative profits or losses comparing semi-extensive production to each type of transhumance. For this analysis, the lambing rates of the transhumance operations were 100\% (worst case), 120\% (likely case) and 150\% (best case), while those of the semi-extensive operation varied from $130 \%$ (worst case), to 150\% (likely case), and 170\% (best case). Feed costs had the greatest uncertainty and variability among surveyed operations. These costs included per ewe stable-feeding costs (for semi-extensive), per ewe pasture lease costs (for transhumants), and per lamb feed costs (all operation types). For the sensitivity analysis, we used a range of these prices in a Monte Carlo simulation using Crystal Ball (Gentry et al. 2008). Given

Table 2 Costs and revenues that are the same for semiextensive and transhumant operations. At the time of data collection in fall 2018, 1 euro $=1.14$ US dollars

\begin{tabular}{lll}
\hline Costs (euros) & Units & Cost \\
Spring, summer, and fall pasture_annual & ewe & 2 \\
Grain for lambs_annual & lamb & 10 \\
Medicines and parasite treatment_annual & ewe & 2.25 \\
Veterinarian fees_annual & ewe & 1.5 \\
Vehicle fuel & km & 0.15 \\
Trucking_per 500 ewe & truckload & 400 \\
Shearing & ewe & 1.3 \\
Insurance & ewe & 0.3 \\
Hired herder compensation & month & 1500 \\
Social security & Annual/worker & 3500 \\
Revenues (euros) & Units & Revenue \\
Sale of lambs & lamb & 67 \\
Sale of wool & ewe & 0.68 \\
Sale of cull ewes & ewe & 10 \\
CAP subsidies & operator & 30,000 \\
\hline
\end{tabular}

the lack of empirical data, we used triangular distributions for all variables, with minimum, most likely, and maximum values reported in Table 4 . The values used in the static analysis are the most likely estimates. Further, given the lack of empirical data, we did not assume any correlation between or among any variables. For all scenarios, it is assumed that enough lambs are kept back to replace $20 \%$ of the mature ewes; however, only $15 \%$ of ewes need to be replaced each year. It is assumed one third of the ewes that need to be replaced each year are sold due to lack of productivity, and the remaining two thirds are replaced due to death. The additional lambs held back as possible replacements that are not needed are sold the following year as culls. As all lambs not held back as replacements are sold, operations with higher lambing percentages will be able to sell more lambs each year.

\section{Results}

Table 5 shows the results of the partial budget analysis for the "Most likely" column in Table 4, for the operation in total, as well as on a per-ewe basis. The results show that transhumant operations by foot tend to be more profitable than those that use trucks, and larger operations tend to benefit more from transhumant management than smaller operations. When comparing the relative profitability of transhumant operations to semiextensive operations across the range of parameter values, transhumant operations tend to be more profitable than their semi-extensive counterparts. Table 6 shows the results of the partial budget analysis across the distributions assumed in Table 4. Similar trends hold, in that larger operations tend to benefit more from transhumant management as compared to smaller operations, and transhumance on foot tends to be more profitable than trucks. On average, across the parameter estimates, semi-extensive operations tend to be less profitable than transhumant operations. Table 7 shows the likelihood of transhumant operations being more profitable than their semi-extensive counterparts based on the simulation. Most (64-78\%) of the time, transhumant 
Table 3 Reproduction characteristics of the different operation types

\begin{tabular}{|c|c|c|c|}
\hline Reproduction characteristics & Semi-extensive & Transhumant trucks & Transhumant foot \\
\hline Lambing percentage (live lambs at weaning) & $1.5 \%$ & $1.2 \%$ & $1.2 \%$ \\
\hline Lambs retained for replacement & $20 \%$ of ewes & $20 \%$ of ewes & $20 \%$ of ewes \\
\hline $\begin{array}{l}\text { Average times a ewe lambs each year (2.5-3 times every } 2 \\
\text { years) }\end{array}$ & 1.3 & 1.3 & 1.3 \\
\hline Average ewe deaths per year & $10 \%$ of herd & $10 \%$ of herd & $10 \%$ of herd \\
\hline Cull ewes sold per year & $5 \%$ of herd & $5 \%$ of herd & $5 \%$ of herd \\
\hline Ram purchases & $\begin{array}{l}\text { None, rams from own } \\
\text { herd }\end{array}$ & $\begin{array}{l}\text { None, rams from own } \\
\text { herd }\end{array}$ & $\begin{array}{l}\text { None, rams from own } \\
\text { herd }\end{array}$ \\
\hline
\end{tabular}

operations are more profitable relative to semi-extensive operations. Again, larger transhumant operations, and those that rely on foot travel, are more likely to be more profitable than semi-extensive operations of the same size. Table 8 shows the impacts that all of the random variables have on the variance of relative profitability. The most important factors contributing to whether transhumance is profitable as compared to semiextensive operations are the relative costs of feeding ewes between the two systems and the productivity of the systems, as measured by lambing rate.

\section{Discussion}

We used a simple analysis of a model of typical sheep operation under three different production systems: semi-extensive where ewes are stable-fed all winter, transhumance by truck, and transhumance by foot, to assess herders' reported observations of the greater profitability of transhumance production systems in the region of the Valles Occidentales of the Aragonese Pyrenees. To our knowledge, this is the first published analysis of the relative profitability of these three production systems in this region or elsewhere in Spain. The analysis demonstrates that for this model typical operation, transhumance on foot is the most profitable production system when costs for all systems are high or typical, lambing rates are low or typical, and herd sizes are large. At small herd sizes (500 ewes) and likely costs, transhumance by foot is only slightly more profitable and transhumance by truck is less profitable than semiextensive management at expected costs and productivity. However, over a range of parameter estimates, both transhumance systems outperform semi-extensive systems under most scenarios. At moderate (1000 ewes) or larger (2000 ewes or more) herd sizes, the relative profitability of transhumance is greater, especially at the large herd sizes. Transhumance by trucks is always relatively less profitable than transhumance on foot, but the patterns are similar relative to semi-extensive production. Semi-extensive per ewe feed costs and lambing rates for all management systems account for most of the difference in profitability among systems.

This analysis thus provides initial evidence of the economic rationality of transhumance under contemporary environmental and economic conditions. It aligns with Perez et al. (2007), who found that some extensive operations in Aragón had a very high technical efficiency even with low lambing rates, due to their efficient and effective use of available resources. Similarly, RipollBosch et al. (2014) found that higher productivity in intensive sheep operations did not translate into greater profitability. Instead, extensive operations that were least reliant on external (purchased) feed sources were most profitable. Our findings also echo those of O'Flanagan

Table 4 Parameter estimates used in the Monte Carlo simulation

\begin{tabular}{|c|c|c|c|}
\hline & Minimum & Most likely & Maximum \\
\hline Semi-extensive lambing rate (live lambs at weaning) & 1.3 & 1.5 & 1.7 \\
\hline Transhumant lambing rate (live lambs at weaning) & 1 & 1.2 & 1.5 \\
\hline Winter pasture costs (transhumant) & 0.04 & 0.06 & 0.13 \\
\hline Feed costs per ewe per day (transhumant) & 0 & 0.01 & 0.02 \\
\hline Feed costs per ewe per day (semi-extensive) & 0.13 & 0.26 & 0.4 \\
\hline Lamb costs per head & 6 & 10 & 16 \\
\hline Vehicle costs (per year) (transhumant) & 3000 & 5000 & 5000 \\
\hline Vehicle costs (per year) (semi-extensive) & 3000 & 3000 & 5000 \\
\hline Fuel costs (km per day) (transhumant) & 30 & 75 & 100 \\
\hline Fuel costs (km per day) (semi-extensive) & 30 & 30 & 100 \\
\hline
\end{tabular}


Table 5 Comparison of relative profitability of transhumant compared to semi-extensive operations based on "Most likely" parameter estimates

\begin{tabular}{|c|c|c|c|c|c|c|}
\hline & 500 ewes by foot & 500 ewes by truck & 1000 ewes by foot & 1000 ewes by truck & 2000 ewes by foot & 2000 ewes by truck \\
\hline Total & $€ 591.25$ & $-€ 208.75$ & $€ 7146.25$ & $€ 5546.25$ & $€ 20,256.25$ & $€ 17,056.25$ \\
\hline Per ewe & $€ 1.18$ & $-€ 0.42$ & $€ 7.15$ & $€ 5.55$ & $€ 10.13$ & $€ 8.53$ \\
\hline
\end{tabular}

et al. (2011), who document the revitalization of transhumance throughout the Ebro River Valley, due to its relative profitability. O'Flanagan et al. (2011) also highlight the role of the European Union Central Agricultural Policy (CAP) subsidies in supporting the economic viability of extensive management. Our analysis also helps explain why operations that aim to expand herd sizes are more likely to switch to transhumance.

There are several limitations to this analysis, which is the first to use this approach to assess the relative profitability of contemporary transhumance. A primary limitation of the current analysis is uncertainty about a number of the assumptions. First, the analysis omitted some types of costs, such as capital investments, interest, and depreciation. Second, there was tremendous variation in feed costs among interviewed operations, including both per ewe stable feeding costs and per ewe pasture lease costs. The sensitivity analysis with Monte Carlo simulations addresses this, but research on a larger sample and over multiple years would provide more robust estimates of average production costs for different operation types. Third, this analysis assumed that all operations spend a similar amount of time on the communal spring, summer, and fall pastures, and all must pay winter feed costs (either grain and hay or leased pasture) for the same amount of time. Fourth, the analysis did not account for potential differences in weight gain and lamb prices but assumed that all operations sell lambs at the same size for the same price. Fifth, the analysis also may have oversimplified transportation costs for the two types of transhumants by assuming that transhumants on foot have no trucking costs, when some operations truck a portion of their herd.

A second limitation is that the analysis does not account for a number of economic and other factors that influence the broader social and economic costs and benefits of transhumance. Broader social costs include family separation or logistical complications of moving children between school systems (Fernández-Giménez 2019). Economic costs that are not accounted for include the labour requirements and costs of long-distance transhumance, and the potential added time and labour costs associated with semi-extensive production such as the time required daily to clean barns and feed confined animals (Fernández-Giménez 2019). We assumed that both types of operations need at least one hired herder when they reach 2000 ewes. In addition, the analysis does not account for potential increased veterinary and animal health costs of semi-extensive operations due to a greater likelihood of disease transmission, animal stress, and less healthy air quality in barns. It also does not factor in opportunity costs, such as additional revenue streams that might be possible under semiextensive management but not transhumance. Lastly, the analysis does not include the transaction costs associated with switching from one operation type to another; it only compares the relative profitability of existing operations of each type.

Table 6 Comparison of relative profitability of transhumant compared to semi-extensive operations based on triangular distributions with parameter estimates in Table 4

\begin{tabular}{|c|c|c|c|c|c|c|}
\hline & 500 ewes by foot & 500 ewes by truck & 1000 ewes by foot & 1000 ewes by truck & 2000 ewes by foot & 2000 ewes by truck \\
\hline \multicolumn{7}{|l|}{ Total } \\
\hline Average & $€ 3516.08$ & $€ 2833.12$ & $€ 10,251.90$ & $€ 8651.90$ & $€ 23,489.46$ & $€ 20,289.46$ \\
\hline Standard deviation & 7422.17 & 7395.97 & $14,600.22$ & $14,600.22$ & $29,104.38$ & $29,104.38$ \\
\hline Minimum & $-€ 22,435.15$ & $-€ 22,989.45$ & $-€ 40,615.81$ & $-€ 42,215.81$ & $-€ 80,683.96$ & $-€ 83,883.96$ \\
\hline Maximum & $€ 32,237.56$ & $€ 31,625.30$ & $€ 65,433.17$ & $€ 63,833.17$ & $€ 132,472.19$ & $€ 129,272.19$ \\
\hline \multicolumn{7}{|l|}{ Per ewe } \\
\hline Average & $€ 7.03$ & $€ 5.67$ & $€ 10.25$ & $€ 8.65$ & $€ 11.74$ & $€ 10.14$ \\
\hline Standard deviation & 14.84 & 14.79 & 14.6 & 14.6 & 14.55 & 14.55 \\
\hline Minimum & $-€ 44.87$ & $-€ 45.98$ & $-€ 40.62$ & $-€ 42.22$ & $-€ 40.34$ & $-€ 41.94$ \\
\hline Maximum & $€ 64.48$ & $€ 63.25$ & $€ 65.43$ & $€ 63.83$ & $€ 66.24$ & $€ 64.64$ \\
\hline
\end{tabular}


Table 7 Probability of transhumant being more profitable than semi-extensive

\begin{tabular}{lccccc}
\hline 500 ewes by foot (\%) & 500 ewes by truck (\%) & 1000 ewes by foot (\%) & 1000 ewes by truck (\%) & 2000 ewes by foot (\%) & 2000 ewes by truck (\%) \\
\hline 67.54 & 64.30 & 75.23 & 71.61 & 78.43 & 75.07 \\
\hline
\end{tabular}

Finally, each operation is unique and transhumant herders often have very individualized approaches to securing pastures, labour for moves, or refining their production system through specialized feeding or other management actions. Individual producers may therefore have particular strategies and circumstances that reduce costs or increase productivity, as other studies have shown (Perez et al. 2007). Thus, it is important that this analysis not be taken to represent the details of any specific operation, but rather to be representative of characteristics that are typical of operations in the region.

Despite these limitations, this study addresses a notable gap in research on the economics of transhumance. Given the growing interest in supporting transhumance in Spain and in the EU more broadly (Bunce et al. 2004; Yilmaz et al. 2019), this study offers initial empirical evidence for the economic rationality of this practice. Previous work has demonstrated the ecological benefits of transhumance (Azcarate et al. 2013; Hevia et al. 2013; Hevia et al. 2016; Manzano and Malo 2006). Further, when the overall sustainability of production is accounted for, extensive systems can be more sustainable, even when less efficient, than more intensive systems (Rodríguez-Ortega et al. 2017). Similarly, when multi-functionality is included in a life cycle analysis, pasture-raised sheep may have a lower total greenhouse gas footprint than intensively raised sheep (Ripoll-Bosch et al. 2013). The promise of combined ecological, economic, and overall sustainability benefits of transhumance suggests that this practice deserves further investigation and potential policy support. Research has established its ecological benefits, herders report economic benefits, and scholars highlight the cultural importance of transhumance (Oteros-Rozas et al. 2012; Oteros-Rozas et al. 2014). Yet, these broader values are not yet reflected in the market prices for meat produced via transhumant management systems and are only partially reflected in EU CAP supports for farming in remote or high nature value regions. In addition, transhumant herders face many challenges to continuing transhumance on foot, including poor condition of the drove roads they rely on, conflicts with other land users, and difficulty in reconciling family life, especially children's schooling, with the transhumant lifestyle (Fernández-Giménez 2019).

\section{Conclusions and implications}

This preliminary analysis illustrates the gains in the profitability of transhumance on foot over semi-extensive livestock production for sheep producers in the Valles Occidentales, especially for larger operations (1000 ewes or more). These results align with interview data from both sheep and cattle producers from the area and provide quantitative evidence to demonstrate the economic rationality for the resurgence in transhumance in this region in recent years. However, this work is based on a limited number of interviews, leaving room for a broader survey of costs and revenues over multiple years

Table 8 Parameter value contributions to variance in relative profitability

\begin{tabular}{|c|c|c|c|c|c|c|}
\hline & $\begin{array}{l}500 \text { ewes by } \\
\text { foot (\%) }\end{array}$ & $\begin{array}{l}500 \text { ewes by } \\
\text { truck (\%) }\end{array}$ & $\begin{array}{l}1000 \text { ewes by } \\
\text { foot (\%) }\end{array}$ & $\begin{array}{l}1000 \text { ewes by } \\
\text { truck (\%) }\end{array}$ & $\begin{array}{l}2000 \text { ewes by } \\
\text { foot }(\%)\end{array}$ & $\begin{array}{l}2000 \text { ewes by } \\
\text { truck (\%) }\end{array}$ \\
\hline $\begin{array}{l}\text { Feed costs per ewe per day } \\
\text { (semi-extensive) }\end{array}$ & 48.87 & 49.23 & 50.51 & 50.51 & 50.84 & 50.84 \\
\hline Transhumant lambing rate & 25.80 & 25.37 & 25.99 & 25.99 & 26.15 & 26.15 \\
\hline Semi-extensive lambing rate & 16.70 & 16.44 & 16.81 & 16.81 & 16.90 & 16.90 \\
\hline Winter pasture costs & 5.20 & 5.25 & 5.40 & 5.40 & 5.44 & 5.44 \\
\hline $\begin{array}{l}\text { Fuel costs (km per day) } \\
\text { (transhumant) }\end{array}$ & 1.42 & 1.43 & 0.37 & 0.37 & 0.10 & 0.10 \\
\hline $\begin{array}{l}\text { Fuel costs (km per day) (semi- } \\
\text { extensive) }\end{array}$ & 1.04 & 1.05 & 0.26 & 0.26 & 0.06 & 0.06 \\
\hline $\begin{array}{l}\text { Vehicle costs (per year) } \\
\text { (transhumant) }\end{array}$ & 0.40 & 0.40 & 0.11 & 0.11 & 0.03 & 0.03 \\
\hline $\begin{array}{l}\text { Vehicle costs (per year) (semi- } \\
\text { extensive) }\end{array}$ & 0.38 & 0.38 & 0.10 & 0.10 & 0.03 & 0.03 \\
\hline $\begin{array}{l}\text { Feed costs per ewe per day } \\
\text { (transhumant) }\end{array}$ & 0.19 & 0.19 & 0.20 & 0.20 & 0.19 & 0.19 \\
\hline Lamb costs per head & 0.00 & 0.26 & 0.27 & 0.27 & 0.27 & 0.27 \\
\hline
\end{tabular}


(including droughts). Additional work could also identify and parameterize other costs and assumptions not included in the current model and test additional scenarios, such as the impact of direct marketing on profitability, for example. Future research could develop a similar model operation and comparison for cattle operations in the area, which have also resumed transhumance albeit over shorter distances. A complete costbenefit analysis would include non-monetary costs and benefits as well, including social costs of transhumance and potentially animal welfare and environmental benefits. Evaluating the effects of exogenous factors such as drought on feed, pasture, and animal prices, and the impacts on relative profitability could help determine whether transhumance is an adaptive strategy under a changing climate. Given the multiple potential benefits of transhumance, additional studies might investigate the level of increased profitability that would incentivize herders to take up transhumance. Finally, our works suggest that a useful tool for producers could be an interactive budgeting tool (such are common in the USA; e.g. Feuz and Ritten 2014) that would allow herders to assess the impacts of various production decisions and marketing strategies on costs, revenue, and profitability. Such a tool could support producer decision-making and planning, especially as environmental and economic conditions shift.

\section{Acknowledgements}

We acknowledge with gratitude the six livestock producers from the Valles Occidentales who provided detailed information on their enterprise budgets and management systems for this analysis, and reviewed initial results, as well as the many other herders who participated in interviews. We thank Federico Fillat, Maite Gartzia, Feliu López-Gelats, Elena Velado Alonso and Jasmine Bruno for their reviews and feedback on various drafts of this work. Thanks to Elena Velado Alonso for Figure 2.

\section{Authors' contributions}

MEF-G conducted the herder interviews in 2010-2011 and 2018-2019, constructed the model operation budget, conducted an initial economic analysis, and drafted the manuscript. JR conducted the final partial budget analysis and simulations, and contributed to writing the methods and results. The authors read and approved the final manuscript.

\section{Funding}

This work was funded by Yolda Initiative, Asociación Trashumancia y Naturaleza and DiversEarth with support from the MAVA Foundation, by a Fulbright Global Scholar Award (2018-2020), and grants from the Spanish Fulbright Commission (2010-2011), and the Center for Collaborative Conservation at Colorado State University (2010-2011).

\section{Availability of data and materials}

Data are available from the authors upon reasonable request.

\section{Ethics approval and consent to participate}

Research was conducted under Colorado State University IRB protocol 350

$-18 \mathrm{H}$, with participants' free, prior and informed consent.

\section{Competing interests}

The authors declare that they have no competing interests.

\section{Author details}

${ }^{1}$ Department of Forest and Rangeland Stewardship, Colorado State University, Campus Mail 1472, Fort Collins, CO 80523-1472, USA. ${ }^{2}$ Agricultural and Applied Economics, University of Wyoming, 1000 E. University Ave., Laramie, WY 82071, USA.

Received: 13 November 2019 Accepted: 4 March 2020

Published online: 18 May 2020

\section{References}

Alimi, T., and V.M. Manyong. 2000. Partial budget analysis for on-farm research. Research guide 65. Ibadan: International Institute for Tropical Agriculture.

Azcarate, F.M., I. Robleno, J. Seoane, P. Manzano, and B. Peco. 2013. Drove roads as local biodiversity reservoirs: Effects on landscape pattern and plant communities in a Mediterranean region. Applied Vegetation Science 16 (3): 480-490. https://doi.org/10.1111/avsc.12003.

Bacaicoa Salaverri, I., J.M. Elías Pastor, and J. Grande Ibarra. 1993. Cuadernos de la trashumancia 8. Albarracín - Cuenca - Molina Madrid: Ministerio de Agricultura, Pesca y Alimentación.

Bamire, A.S., and V.M. Manyong. 2003. Profitability of intensification technologies among smallholder maize farmers in the forest-savanna transition zone of Nigeria. Agriculture, Ecosystems and Environment 100: 111-118.

Bunce, R.G.H., M. Perez-Soba, R.H.G. Jongman, A. Gomez Sal, F. Herzog, and I. Austad, eds. 2004. Transhumance and biodiversity in European mountains. Wageninen: Alterra Wageninen.

Casas Nogales, R., and P. Manzano Baena. 2007. Valoración económico de pastoralismo en Espana [In Spanish, Economic valuation of pastoralism in Spain]. Nairobi, Kenya: IUCN World Initiative for Sustainable Pastoralism.

Chocarro, C., R. Fanlo, F. Fillat, and P. Marin. 1990. Historical evolution of naturalresource use in the Central Pyrenees of Spain. Mountain Research and Development 10 (3): 257-265.

Cuadrat, J.M., M.A. Saz, and S.M. Vicente-Serrano. 2007. Atlas Climático de Aragón. Zaragoza: Government of Aragón.

Davies, J., and R. Hatfield. 2007. The economics of mobile pastoralism: A global summary. Nomadic Peoples 11 (1): 91-116.

Eisele, K., J. Ritten, C.T. Bastian, S. Paisley, and S. Lake. 2012. Economic comparison of weaning and feeding strategies for beef production. Journal of the American Society of Farm Managers and Rural Appraisers 73 (5): 124-134.

Estrada, F., E. Nadal, and J.R. Iglesias. 2010. Twenty-first century transhumants: Social and economic change in the Alta Ribagorca. In Social and ecological history of the Pyrenees: State, market and landscape, ed. I. Vaccaro and O. Beltran, 105-126. Walnut Creek: Left Coast Press.

Fernández-Giménez, M. 2019. Co-creating knowledge for action with transhumant herders in Spain. Ankara, Turkey: Yolda Initiative and Roads Less Travelled Partnership.

Fernandez-Gimenez, M.E., and F.F. Estaque. 2012. Pyrenean pastoralists' ecological knowledge: Documentation and application to natural resource management and adaptation. Human Ecology 40 (2): 287-300. https://doi. org/10.1007/s10745-012-9463-x.

Fernandez-Gimenez, M.E., and F. Fillat Estaque. 2012. Pyrenean pastoralists' observations of environmental change: An exploratory study in Los Valles Occidentales of Aragón. Pirineos 167: 145-165.

Fernandez-Gimenez, M.E., and S. LeFebre. 2006. Mobility in pastoral systems: Dynamic flux or downward trend? International Journal of Sustainable Development and World Ecology 13: 1-22.

Feuz, B., T. Petry, D. Anderson, L. Meyer, K. Andries, J. Lampson, and J. Robb. 2013. U.S. Baseline lamb cost of production model. WERA 39 report. Accessed online at: https://d1 carq366w3ike.cloudfront.net/http/DOCUMENT/ SheepUSA/COP\%20Project\%20\%20Summary\%20Low.pdf.

Feuz, B., and J. Ritten. 2014. An effective combination: Partial budgeting and sensitivity analysis. Laramie: University of Wyoming Extension.

Foro-Ciudad.com. 2019. Municipios y localidades de la provincia de Huesca. ForoCiudad.com https://www.foro-ciudad.com/huesca.html. Accessed 1 Nov 2019.

Fratkin, E., and E. Abella Roth, eds. 2005. As pastoralists settle. New York: Klewer Academic Publishers.

Galanopoulos, K., Z. Abas, V. Laga, L. Hatziminaoglou, and J. Boyazoglu. 2011. The technical efficiency of transhumance sheep and goat farms and the effect of EU subsidies: Do small farms benefit more than large farms? Small Ruminant Research 100 (1): 1-7. https://doi.org/10.1016/j.smallrumres.2011.05.008. 
Garzón-Heydt, J. 2004. Recovering transhumance in Spain for long-term nature conservation. In Transhumance and biodiversity in European mountains, ed. R. G.H. Bunce, M. Pérez-Soba, R.H.G. Jongman, A. Gómez Sal, F. Herzog, and I. Austad, 259-264. Wageningen: Alterra.

Gaspar, P., F.J. Mesias, M. Escribano, and F. Pulido. 2009. Assessing the technical efficiency of extensive livestock farming systems in Extremadura, Spain. Livestock Science 121: 7-14.

Geddes, D.S. 1983. Neolithic transhumance in the Mediterranean Pyrenees. World Archaeology 15 (1): 51-66.

Gentry, B., D. Blankenship, and E. Wainwright. 2008. Oracle crystal ball user manual. 11.1. Denver: Orable Inc..

Hamadeh, S.K., G.N. Bistanji, M.R. Darwish, M. Abi Said, and D. Abi Ghanem. 2001 Economic sustainability of small ruminants production in semi-arid areas of Lebanon. Small Ruminant Research 40: 41-49.

Hevia, V., F.M. Azcarate, E. Oteros-Rozas, and J.A. Gonzalez. 2013. Exploring the role of transhumance drove roads on the conservation of ant diversity in Mediterranean agroecosystems. Biodiversity and Conservation 22 (11): 25672581. https://doi.org/10.1007/s10531-013-0539-8.

Hevia, V., J. Bosch, F.M. Azcarate, E. Fernandez, A. Rodrigo, H. Barril-Graells, and J. A. Gonzalez. 2016. Bee diversity and abundance in a livestock drove road and its impact on pollination and seed set in adjacent sunflower fields. Agriculture Ecosystems \& Environment 232: 336-344. https://doi.org/10.1016/j. agee.2016.08.021.

Honeychurch, William. 2010. Pastoral nomadic voices: a Mongolian archaeology for the future. World Archaeology 42 (3): 405-417. https://doi.org/10.1080/ 00438243.2010 .497389$.

Humphrey, C., and D. Sneath. 1999. The end of nomadism? Durham: Duke University Press.

Instituto Aragonés de Estadística. 2018a. Estadística local de Aragón. Ficha territorial. Municipio Ansó. Zaragoza: Instituto Aragonés de Estadística.

Instituto Aragonés de Estadística. 2018b. Estadística local de Aragón. Ficha territorial. Municipio Valle de Hecho. Zaragoza: Instituto Aragonés de Estadística.

Kay, R., W. Edwards, and P. Duffy. 2016. Farm management. 8th ed. New York: McGraw Hill Publishers.

Lefebvre, M., M. Espinosa, and S. Gomez y Paloma. 2012. The influence of the Common Agricultural Policy on agricultural landscapes. Report EUR 25459 EN edited by European Commission Joint Research Center Scientific and Technical Policy Reports. Seville: European Commission Joint Research Centre Institute for Prospective Technological Studies.

Legesse, G., G. Abebe, and K. Ergano. 2005. The economics of goats managed under different feeding systems. Livestock Research for Rural Development 17 (66). http://www.lrrd.org/lrrd17/6/lege17066.htm.

Lutta, A.I., L.W. Robinson, O.V. Wasonga, E. Ruto, J. Sircely, and M.M. Nyangito. 2019. Economic valuation of grazing management practices: Discrete choice modeling in pastoral systems of Kenya. Journal of Environmental Planning and Management. https://doi.org/10.1080/09640568.2019.1584097.

Manzano Baena, P., and R. Casas. 2010. Past, present and future of trashumancia in Spain: Nomadism in a developed country. Pastoralism 1 (1): 72-90.

Manzano, P., and J.E. Malo. 2006. Extreme long-distance seed dispersal via sheep. Frontiers in Ecology and Environment 4 (5): 244-248.

Martin Casas, J. 2003. Las Vias Pecuarias del Reino de España Un Patrimonio Natural y Cultural Europeo. Madrid: Ministerio del Medio Ambiente.

Mazzocchi, C., and G. Sali. 2019. Assessing the value of pastoral farming in the Alps using choice experiments: Evidence for public policies and management. Journal of Environmental Planning and Management 62 (4): 552-567. https://doi.org/10.1080/09640568.2018.1430557.

Niamir-Fuller, M., ed. 1999. Managing mobility in African rangelands. London: Intermediate Technology Publications.

Nyariki, D.M., and D.A. Amwata. 2019. The value of pastoralism in Kenya: Application of total economic value approach. Pastoralism-Research Policy and Practice 9. https://doi.org/10.1186/s13570-019-0144-x.

O'Flanagan, P., T.L. Martinez, and M.P.E. Abad. 2011. Restoration of sheep transhumance in the Ebro Valley, Aragon, Spain. Geographical Review 101 (4): 556-575. https://doi.org/10.1111/j.1931-0846.2011.00117.x.

Oteros-Rozas, E., J.A. Gonzalez, B. Martin-Lopez, C.A. Lopez, P. Zorrilla-Miras, and C. Montes. 2012. Evaluating ecosystem services in transhumance cultural landscapes an interdisciplinary and participatory framework. Gaia-Ecological Perspectives for Science and Society 21 (3): 185-193. https://doi.org/10.14512/gaia.21.3.9.

Oteros-Rozas, E., B. Martin-Lopez, J.A. Gonzalez, T. Plieninger, C.A. Lopez, and C. Montes. 2014. Socio-cultural valuation of ecosystem services in a transhumance social-ecological network. Regional Environmental Change 14 (4): 1269-1289. https://doi.org/10.1007/s10113-013-0571-y.

Oteros-Rozas, E., R. Ontillera-Sanchez, P. Sanosa, E. Gomez-Baggethun, V. ReyesGarcia, and J.A. Gonzalez. 2013. Traditional ecological knowledge among transhumant pastoralists in Mediterranean Spain. Ecology and Society 18 (3) https://doi.org/10.5751/es-05597-180333.

Pallaruelo, S. 1993. Pirineo Aragonés. Cuadernos de la Trashumancia. Madrid: Ministerio de Agricultura, Pesca y Alimentación.

Perez, J.P., J.M. Gil, and I. Sierra. 2007. Technical efficiency of meat sheep production systems in Spain. Small Ruminant Research 69: 237-241.

Perez, M.R., and A.V. Saez. 1990. Transhumance with cows as a rational land-use option in the Gredos Mountains (central Spain). Human Ecology 18 (2): 187-202.

Puigdefabregas, J., and F. Fillat. 1986. Ecological adaptation of traditional land uses in the Spanish Pyrenees. Mountain Research and Development 6 (1): 63-72.

Qtaishat, T., A. Al-Sharafat, and M.I. Majdalawi. 2012. A comparative economic analysis of sheep production systems: A case study of Jordan. Journal of Food, Agriculture and Environment 10 (2): 690-694.

Ripoll-Bosch, R., I.J.M. de Boer, A. Bernués, and T.V. Vellinga. 2013. Accounting for multi-functionality of sheep farming in the carbon footprint of lamb: A comparison of three contrasting Mediterranean systems. Agricultural Systems 116: 60-68. https://doi.org/10.1016/j.agsy.2012.11.002.

Ripoll-Bosch, R., M. Joy, and A. Bernués. 2014. Role of self-sufficiency, productivity and diversification on the economic sustainability of farming systems with autochthonous sheep breeds in less favoured areas in Southern Europe. Animal 8 (8): 1129-1237.

Rodriguez Pascual, M. 2001. La trashumancia: cultural, canadas y viajes. 5th ed. Leon: Edilesa.

Rodríguez-Ortega, T., A. Bernués, A.M. Olaizola, and M.T. Brown. 2017. Does intensification result in higher efficiency and sustainability? An emergy analysis of Mediterranean sheep-crop farming systems. Journal of Cleaner Production 144: 171-179. https://doi.org/10.1016/j.jclepro.2016.12.089.

Rogers, E. 1995. Diffusion of innovations. 4th ed. New York: The Free Press.

Ruiz, M., and J.P. Ruiz. 1986. Ecological history of transhumance in Spain. Biological Conservation 37: 73-86.

Scoones, l., ed. 1994. Living with uncertainty: New directions in pastoral development in Africa. London: Intermediate Technology Publications.

Shomo, F., M. Ahmed, K. Shideed, A. Aw-Hassan, and O. Erkan. 2010. Sources of technical efficiency of sheep production systems in dry areas of Syria. Small Ruminant Research 91: 160-169.

Starrs, P.F. 2018. Transhumance as antidote for modern sedentary stock raising. Rangeland Ecology \& Management 71 (5): 592-602. https://doi.org/10.1016/j. rama.2018.04.011.

Yilmaz, E., L. Zogib, P. Urivelarrea, and S. Demibras Caglayan. 2019. Mobile pastoralism and protected areas: Conflict, collaboration and connectivity. Parks 25 (1): 7-24.

\section{Publisher's Note}

Springer Nature remains neutral with regard to jurisdictional claims in published maps and institutional affiliations.

\section{Submit your manuscript to a SpringerOpen ${ }^{\oplus}$ journal and benefit from:}

- Convenient online submission

- Rigorous peer review

- Open access: articles freely available online

- High visibility within the field

- Retaining the copyright to your article

Submit your next manuscript at $>$ springeropen.com 